\title{
A case of colistin-induced fixed drug eruption
}

\author{
Kolistine bağı fiks ilaç erüpsiyonu olgusu
}

İsmail Necati Hakyemez ${ }^{1}$, Abdulkadir Küçükbayrak², Aslıhan Burcu Yıkılgan², Elif Sultan Bolaç3, Nebil Yıldız ${ }^{3}$, Çetin Boran ${ }^{4}$, Hayrettin Akdeniz ${ }^{2}$

\begin{abstract}
Several medicines, especially antimicrobials, play a role in the etiology of fixed drug eruption (FDE). The clinical manifestation is quite typical for a drug-induced reaction. FDE which developed in an 83-year-old male patient who has been administered colistin due to Acinetobacter pneumonia is presented here since it is very rarely seen. Therefore colistin should also be considered in the differential diagnosis of FDE. J Clin Exp Invest 2013; 4 (3): 374-376
\end{abstract}

Key words: Fixed drug eruption, etiology, colistin

\section{INTRODUCTION}

Antibiotics, antifungal drugs, analgesics, anticonvulsants and sedatives are known to play a role in etiology of fixed drug eruption. Among antibiotics, trimethoprim-sulfamethoxazole and tetracyclines are the most frequently accused drugs $[1,2]$. Colistin is a polymyxin group antibiotic used for treatment of the infections emerging with multi-resistant gram negative bacilli. Besides serious side effects such as nephrotoxicity and neurotoxicity, it may rarely lead to itching and skin rashes [3]. FDE which developed in an 83 years old male patient who has been administered colistin due to Acinetobacter pneumonia is presented.

\section{CASE}

An 83-year-old male patient was admitted to the hospital for the diagnosis of cerebrovascular occlusion. Bilateral diffuse rales were auscultated in his physical examination and infiltrations were detected in bilateral lower zones on the chest radiograph

\section{ÖZET}

Fiks ilaç erüpsiyonu (FIE) etyolojisinde başta antimikrobiyaller olmak üzere çeşitli ilaçlar rol almaktadır. Klinik görünümü, ilaca bağlı gelişen bir reaksiyon için oldukça tipiktir. Literatürde, kolistine bağlı gelişen fiks ilaç erüpsiyonu olgusu bildirilmemiştir. Acinetobacter pnömonisi nedeniyle kolistin kullanılan 83 yaşındaki bir erkek hastada ortaya çıkan fiks ilaç erüpsiyonu, çok nadir görülmesi açısından sunulmuştur. FİE ayırıcı tanısında kolistinin yer alabileceği akılda tutulmalıdır.

Anahtar kelimeler: Fiks ilaç erüpsiyonu, etyoloji, kolistin

of the patient who developed symptoms of fever and sputum. Because of Acinetobacter baumannii growth in the culture of sputum, the patient was put on intravenous and inhaler colistimethate sodium (prodrug form of colistin) (Colimycin $\AA$ ) therapy with the diagnosis of pneumonia. The patient developed a sharply circumscribed, annular, erythematous hemorrhagic bullous skin lesion of $3 \times 2 \mathrm{~cm}$ in size in the anterior abdominal wall on the second day of the treatment, and it turned into a hyperpigmented lesion on the seventh day (Figure 1). No any other skin symptom was found in the patient. Skin biopsy was carried out from the lesion by the dermatology department with the provisional diagnoses of traumatic bulla and FDE. Colistin was continued for one week because of the severe pneumonia. Pathological examination of the lesion was consistent with the diagnosis of fixed drug eruption (Figure 2). The patient was diagnosed with fixed drug based on the clinic and pathologic findings. Fusidic acid- betamethasone valerate (fucicort $\circledast$ ) cream was administered topically.

\footnotetext{
${ }^{1}$ Sevket Yilmaz Education and Research Hospital, Department of Infectious Diseases and Clinical Microbiology, Bursa, Turkey

${ }^{2}$ Abant Izzet Baysal University, Faculty of Medicine, Department of Infectious Diseases and Clinical Microbiology, Bolu, Turkey

${ }^{3}$ Abant Izzet Baysal University, Faculty of Medicine, Department of Neurology, Bolu, Turkey

${ }^{4}$ Abant Izzet Baysal University, Faculty of Medicine, Department of Pathology, Bolu, Turkey

Correspondence: İsmail Necati Hakyemez,

Sevket Yilmaz Education and Research Hospital Department of Infectious Diseases and Clinical Microbiology, Bursa, Turkey Email: drinh@hotmail.com

Received: 19.04.2013, Accepted: 10.06.2013

Copyright (C JCEI / Journal of Clinical and Experimental Investigations 2013, All rights reserved
} 


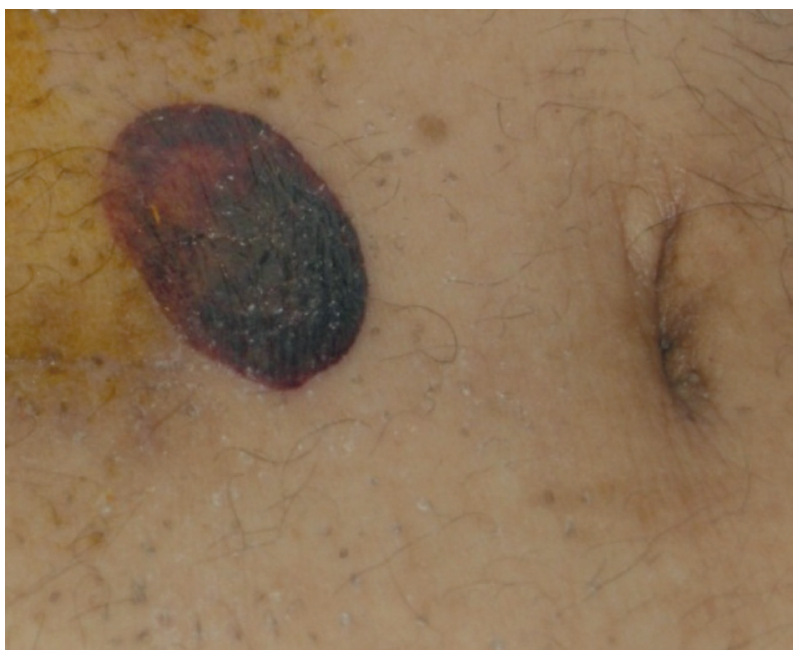

Figure 1. Sharply circumscribed, annular and hemorrhagic lesion in the anterior abdominal wall

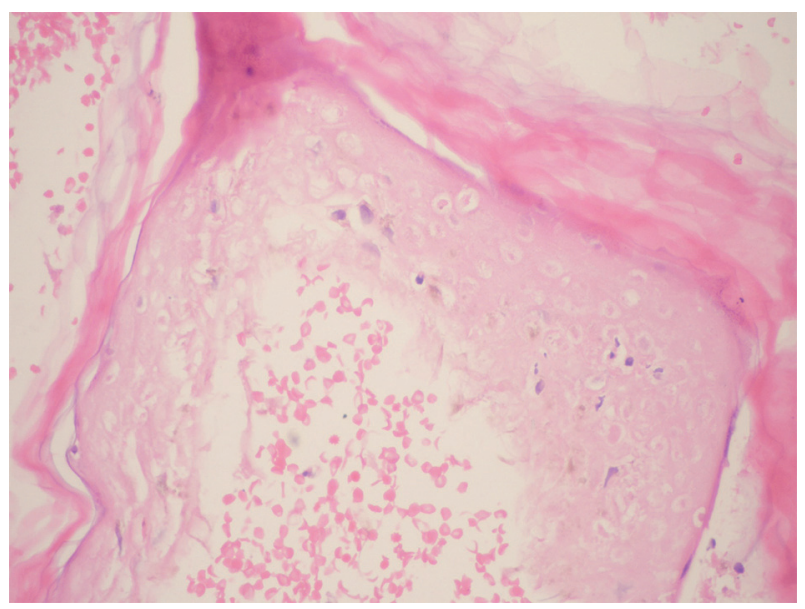

Figure 2. Separation at the level of dermoepidermal junction, confluent epidermal necrolysis, intraepidermal lymphocytes and erythrocytes on the edematous ground in the subepidermal area (H\&E, x200)

\section{DISCUSSION}

Clinical manifestation of FDE is quite pathognomonic for a drug-induced reaction [4]. In FDE, lesion is typically sharply circumscribed, round or oval, reaching up to $10 \mathrm{~cm}$ in diameter, purplish and mildly swollen from the skin. In general, postlesional pigmentation remains at the site of healing lesions. Often it is in the form of single lesion, but in some cases a large number of lesions may be seen and generalized FDE may even develop [1]. Antibodydependent cellular cytotoxicity plays an important role in the pathogenesis of FDE. In addition, it may also be associated with genetic factors [5].
The most accused agents in FDE include antimicrobials, non-steroidal anti-inflammatory drugs, sedatives, quinine and oral contraceptives. Among antimicrobials; tetracyclines, sulfonamides, penicillins and metronidazole are accused in the etiology. FDE generally emerges between 30 minutes and 16 hours after the drug intake, and occasionally this duration may be prolonged up to 48 hours. Although skin lesions are usually asymptomatic, sometimes they may painful, and burning. The lesions persist if the drug is continued and disappear within several weeks after it is discontinued. If the responsible drug is taken again, lesions may repeat in the same site. The genital skin is the most involved region, but anywhere in the body may be affected [6]. In our patient, the lesion emerged in the anterior abdominal wall. Drug reactions are seen more frequently in the elderly due to using a large number of drugs [7]. Our patient was in the geriatric age group.

Diagnosis of the disease is usually established with typical appearance of the lesion. Histopathological examination is helpful for the diagnosis. In the biopsy made from the lesion; degeneration of the basal layer, edema in the papillary dermis and subepidermal bulla formation, diffuse lymphocytic infiltration in the dermoepidermal junction accompanied by eosinophils and necrotic keratinocytes are found [8]. In our case, the biopsy carried out from the lesion was consistent with FDE. For the confirmation of the diagnosis, systemic oral provocation tests can be performed, but these tests are not recommended by some authors due to the risk of generalized bullous eruption. Instead, topical and intradermal provocation tests are recommended [9].

Colistin is a polymyxin group antibiotic acting by injuring the cytoplasmic membrane. Colistimethate sodium is the prodrug form of colistin and is inactive. It acts by turning into colistin after taken into the body. Mild itching may be seen in $20 \%$ of patients in taken colistimethate sodium, which doesn't require the drug to be discontinued. This is resulted from the histamine-releasing effects of polymyxins. Rarely, contact dermatitis, macular rash, urticaria, ototoxicity, drug fever and gastrointestinal disorders may occur during the treatment [10].

The most effective approach to the treatment of FDE is discontinuation of the drug. In addition, topical corticosteroids can be applied in the non-eroded lesions, wet dressing plus topical corticosteroids can be administered in the eroded lesions, and systemic corticosteroid therapy may be given for about two weeks in the patients with diffuse involvement $[1,8]$. In our patient; we continued to the colistin therapy for one week due to severe pneumonia. In 
addition, a clinical response of FDE was achieved with topical supportive therapy.

Colistin is often the only option in multidrug-resistant nosocomial Acinetobacter infections. Thus, it is the most preferred antimicrobial in the treatment. To the best of our knowledge, there is no published report of colistin-induced FDE in the literature. Therefore, among the antimicrobial agents accused in the etiology of FDE, colistin should definitely be considered in the differential diagnosis.

\section{REFERENCES}

1. Ozkaya E. Fixed drug eruption: state of the art. J Dtsch Dermatol Ges 2008;6:181-188.

2. Patel RM, Marfatia YS. Clinical study of cutaneous drug eruptions in 200 patients. Indian J Dermatol Venereol Leprol 2008;74:430.

3. Yahav D, Farbman L, Leibovici L, Paul M. Colistin: new lessons on an old antibiotic. Clin Microbiol Infect 2012;18:18-29.
4. Shiohara T. Fixed drug eruption: pathogenesis and diagnostic tests. Curr Opin Allergy Clin Immunol 2009;9:316-321.

5. Bircher AJ, Scherer K. Delayed cutaneous manifestations of drug hypersensitivity. Med Clin North Am 2010;94:711-725.

6. Wolff K, Johnson RA, Suurmond D. Fitzpatrick's color atlas and synopsis of clinical dermatology. New York: McGraw Hill, 2005:556-558.

7. Arıcan Ö, Ürün M. A case of tenoxicam induced generalized (multifocal) bullous fixed drug eruption. Turkish Journal of Geriatrics 2008;11:200-203.

8. Horn TD, Hiatt KM. Cutaneous Toxicities of Drugs. In: Elder DE, Elenitsas R, Johnson BL, Murphy GF, ed. Lever's Histopathology of the Skin. Philadelphia, JB Lippincott Co, 2005:324-345.

9. Habif T. Exanthems and Drug Eruptions. In: Clinical Dermatology: A Color Guide to Diagnosis and Therapy. Philadelphia: Mosby, 2009:541-580.

10. Falagas ME, Kasiakou SK. Toxicity of polymyxins: a systematic review of the evidence from old and recent studies. Crit Care 2006;10:27. 